\title{
KEGIATAN MENULIS KREATIF SASTRA PADA SISWA KELAS VII SMP DI JAKARTA TIMUR SEBAGAI WUJUD GERAKAN LITERASI SEKOLAH
}

\author{
Endang Sulistijani, Arinah Fransori, dan Friza Youlinda \\ Universitas Indraprasta PGRI \\ Endang711@yahoo.co.id
}

\begin{abstract}
Abstrak
Tujuan penulisan makalah ini adalah memaparkan tentang kegiatan menulis kreatif pada siswa kelas VII SMP di Jakarta Timur. Kegiatan ini dilakukan oleh tim dosen, mahasiswa, serta alumni Program Studi Bahasa Indonesia Universitas Indraprasta PGRI sebagai wujud Tri Dharma Perguruan Tinggi dalam Pengabdian Kepada Masyarakat. Pelaksanaan kegiatan ini berlangsung selama dua hari pada dua sekolah yang berbeda. Metode yang digunakan dalam kegiatan menulis kreatif ini adalah metode ceramah dan brainstorming. Selain itu, tim abdimas juga menggunakan metode demonstrasi dalam memaparkan tahap-tahap atau proses menulis kreatif sastra sesuai pengalamannya dalam cipta sastra. Dengan kegiatan menulis kreatif sastra baik menulis puisi ataupun cerpen, diharapkan semakin tumbuh dan berkembang tindakan nyata literasi sekolah sehingga semakin banyak siswa menghasilkan karya sastra. Oleh karena itu, hasil luaran dari kegiatan ini adalah penerbitan antologi puisi dan antologi cerpen karya siswa.
\end{abstract}

\begin{abstract}
The purpose of writing this paper is to describe creative writing activities for seventh grade students in East Jakarta. This activity was carried out by a team of lecturers, students and alumni of the Indonesian Language Study Program at Indraprasta PGRI University as a form of the Tri Dharma of Higher Education in Community Service. The implementation of this activity lasted for two days at two different schools. The method used in this creative writing activity is the lecture and brainstorming methods. In addition, the Community Service team also used a demonstration method in describing the stages or process of creative writing of literature according to its experience in literary copyright. With literary creative writing activities both writing poetry or short stories, from these our team expected that the more real growth and development of school literacy will occur so that more students produce literary works. Therefore, the outcome of this activity is the publication of Short Story Poetry and Antalogy book by students.
\end{abstract}

\section{Pendahuluan}

Proses pembelajaran sastra di sekolah saat ini menekankan penerapan literasi sekolah. Gerakan literasi sekolah adalah gerakan mengenalkan anak-anak pada dunia membaca, mengenalkan buku-buku sastra sejak dini dan membiasakan anak-anak untuk berlatih menulis. 
Pada prosesnya dalam tahap pembiasaan, iklim literasi sekolah diarahkan pada pengadaan dan pengembangan lingkungan fisik, serta budaya membaca seperti: buku-buku nonpelajaran (novel, kumpulan cerpen, buku ilmiah populer, majalah, komik, dsb).

Menurut Retnaningdyah (2016: 2) literasi sekolah dalam konteks Gerakan Literasi Sekolah (GLS) adalah kemampuan mengakses, memahami, dan menggunakan sesuatu secara cerdas melalui berbagai aktivitas, antara lain membaca, melihat, menyimak, menulis, dan/atau berbicara. GLS merupakan sebuah upaya yang dilakukan secara menyeluruh untuk menjadikan sekolah sebagai organisasi pembelajaran yang warganya literat sepanjang hayat melalui pelibatan publik.

Keempat keterampilan berbahasa, seperti disebutkan di atas, bukanlah semata-mata kemampuan bawaan yang dimiliki seorang siswa, melainkan hasil dari proses belajar dan berlatih secara terus menerus. Selain itu, adanya dorongan yang kuat dan peran aktif guru turut menentukan keterampilan berbahasa seorang siswa. Artinya, keterampilan itu tidak hanya ditentukan oleh siswa itu sendiri, tetapi juga ditentukan oleh faktor eksternal, misalnya kemampuan guru dalam memilih teknik pembelajaran yang dapat menggugah siswa untuk terampil berbahasa atau peran serta seluruh stakeholder yang menjadi bagian dari sekolah dan masyarakat yang mendukung Gerakan Literasi Sekolah.

Pembinaan Gerakan Literasi Sekolah khususnya menulis karya sastra, pada dasarnya, adalah suatu usaha untuk memunculkan potensi kreatif pada diri peserta pembinaan dalam bentuk tulis. Hal ini berarti pembinaan menulis karya sastra memiliki dua tanggung jawab utama. Tanggung jawab pertama adalah memunculkan potensi kreatif dalam bidang kesastraan, seperti mengembangkan ide: (a) mengembangkan ide dengan memanfaatkan imajinasi dan fakta lapangan, (b) menjabarkan ide ke dalam cerita dan tokoh, (c) menunjukkan kepiawaian "bertutur" dalam plot dan penokohan. Untuk itu, pembinaan menulis karya sastra tidak boleh bersifat top down dan mencetak penulis menurut versi pembinanya. Tanggung jawab kedua adalah mengembangkan kemampuan menuangkan potensi kreatif tersebut ke dalam bentuk tulis, yang meliputi (a) penguasaan bahasa secara fully fledge, (b) kemampuan menata "tuturan" dalam bahasa yang tepat dan berpijak pada karakter tokoh dan alur cerita, serta (c) kemampuan menerapkan aturan kepenulisan seperti penulisan paragraph, dialog, dan 
penerapan ejaan. Oleh karena itu, usaha pembinaan menulis karya sastra harus dilandasi oleh kemampuan kesastraan, kebahasaan, kekulturan, dan psikologi.

Kondisi pembinaan menulis karya sastra saat ini masih jauh dari situasi ideal. Di antara dua tanggung jawab utama, pembina cenderung timpang pada satu sisi. Hal itu pun belum sepenuhnya optimal. Pembinaan kadang-kadang lebih menekankan pada satu sisi baik orisinalitas ide, kemerdekaan imajinasi, teknik menulis, atau memasukkan kediriannya dalam diri peserta didik. Melalui abdimas ini, diharapkan kegiatan literasi sekolah khususnya menulis kreatif dalam bidang sastra dapat mengenalkan bagaimana menulis karya sastra dilandasi oleh kemampuan kesastraan, kebahasaan, budaya, dan kejiwaan penulisnya.

Tim abdimas yang terdiri dari dosen-dosen Program Pendidikan Bahasa Indonesia, beberapa mahasiswa Universitas PGRI serta alumni sangat peduli dengan Gerakan Literasi ini, khususnya menulis karya sastra. Dengan berkunjung ke beberapa Sekolah Menengah Pertama di Kecamatan Pasar Rebo, tim abdimas mendapatkan beberapa temuan yang berkaitan dengan hal tersebut dan menetapkan dua mitra Sekolah Menengah Pertama (Swasta) sebagai mitra abdimas yaitu SMP Ign. Slamet Riyadi dan SMP Kartika VIII - I.

\section{Metode Penelitian}

Kegiatan abdimas ini berbentuk sosialisasi atau pelatihan menulis kreatif sastra pada kelas VII di SMP Ign. Slamet Riyadi dan SMP Kartika VIII - I Jakarta Timur. Dalam pelaksanaan sosialisasi, tim abdimas menggunakan metode ceramah, demonstrasi, dan brainstorming.

Metode ceramah dapat diartikan sebagai cara dalam menjelaskan materi yang hendak disampaikan secara lisan kepada peserta. Dalam kegiatan sosialisasi ini, tim abdimas menggunakan metode ceramah ini untuk menjelaskan apa itu gerakan literasi, manfaat dari gerakan literasi, arti kreatif, bentuk-bentuk kreativitas dan contoh-contohnya, kreativitas dalam karya sastra, dan lain sebagainya. Metode ceramah ini bertujuan untuk memberikan pengayaan kepada siswa tentang Gerakan Literasi Sekolah dan memberikan apersepsi kepada siswa tentang kegiatan menulis terutama menulis karya sastra.

Materi yang perlu dijelaskan pada peserta didik adalah seputar dunia sastra, misalnya pemahaman puisi dan sturktur yang membangun puisi serta cerpen dan unsur-unsurnya. Selain itu juga manfaat dari menulis kreatif sastra. 
Metode demonstrasi digunakan untuk menyajikan secara langsung contoh praktik menulis kreatif baik menulis puisi ataupun cerpen. Menurut Huda (2014: 232) demonstrasi adalah penyajian pelajaran dengan memperagakan dan mempertunjukkan suatu proses, situasi, atau benda tertentu yang sedang dipelajari baik dalam bentuk sebenarnya maupun dalam bentuk tiruan yang dipertunjukkan oleh pengajar atau sumber belajar lain di depan seluruh siswa. Metode ini bertujuan agar siswa dapat dengan mudah dan jelas melakukan praktik menulis kreatif karya sastra.

Dalam metode demonstrasi ini, tim abdimas beserta mahasiswa memberikan stimulus berupa tahap pembuatan puisi, contoh-contoh antologi puisi dan cerpen karya dari ketua serta anggota tim abdimas. Selain itu, disajikan pula musikalisasi dari puisi mahasiswa Universitas PGRI Jakarta. Dengan stimulus ini diharapkan peserta didik tertarik dan menjadi semakin berani bertanya tentang menulis kreatif sastra.

Metode lain yang digunakan dalam kegiatan sosialisasi menulis karya sastra ini adalah brainstorming. Metode brainstorming adalah teknik pembelajaran yang dilakukan dalam kelompok yang peserta didiknya memiliki latar belakang pengetahuan dan pengalaman yang berbeda-beda. Setiap siswa pada umumnya memiliki kemampuan dan pengetahuan menulis yang berbeda-beda. Bagaimana dengan satu tema dapat menjadikan berbagai jenis tulisan yang bervariasi. Kegiatan ini dilakukan untuk menghimpun gagasan atau pendapat dalam rangka menemukan, memilih, dan menentukan berbagai pernyataan sebagai jawaban terhadap pertanyaan yang berkaitan dengan kebutuhan belajar, sumber-sumber, hambatan, dan lain sebagainya.

Menurut White (2000: 18) brainstorming adalah cara yang efektif dan banyak digunakan untuk memperoleh gagasan. Gagasan yang diperoleh dapat berupa gagasan dan konten yang aktual, atau gagasan yang berfungsi untuk mengorganisasikan ide. Dalam metode brainstorming ini terdapat tahapan-tahapan yang harus dilalui sebagai berikut.

\section{a. Pemberian Informasi dan Motivasi}

Pada tahap ini guru memberikan materi ajar dan latar belakangnya, lalu mengajak siswa agar aktif dan memberikan tanggapannya. 
b. Identifikasi

Siswa diajak memberikan sumbang saran dan gagasan sebanyak-banyaknya dan ditampung tanpa dikritik secara langsung.

c. Klasifikasi

Mengklasifikasikan berdasarkan criteria yang disepakati oleh kelompok. Klasifikasi juga bisa didasarkan faktor-faktor lain yang mendukung

d. Verifikasi

Meninjau kembali gagasan-gagasan yang telah diklasifikasikan. Setiap gagasan diuji relevansinya dengan masalah yang dibahas. Apabila terdapat kesamaan gagasan maka yang diambil yang relevan dengan pembahasan.

e. Konklusi

Guru memimpin para siswa untuk menyimpulkan butir-butir alternatif pemecahan masalah yang disetujui atau disepakati bersama.

Pada tahap pemberian informasi dan motivasi ini, tim abdimas lebih menekankan pada contoh-contoh yang sederhana dalam pembuatan puisi yang sederhana. Sebagian contoh puisi yang ditampilkan adalah puisi-puisi Sapardi Joko Damono, Toto S Bachtiar, dan juga puisi-puisi karya tim abdimas.

Tahap selanjutnya, adalah identifikasi. Dalam tahap ini, tim abdimas meminta ide atau bertanya jawab tentang gagasan yang sedang diangkat dalam dunia pendidikan. Saran yang diminta oleh peserta didik adalah gagasan yang berkaitan dengan pendidikan karakter. Oleh karena pendidikan karakter meliputi beberapa jenis, tim abdimas kembali menjelaskan hal tersebut

Ada empat jenis karakter yang selama ini dikenal dan dilaksanakan dalam proses pendidikan, yaitu:

a. pendidikan karakter berbasis nilai religius, yang merupakan kebenaran wahyu tuhan (konservasi moral).

b. pendidikan karakter berbasis nilai budaya, antara lain yang berupa budi pekerti, pancasila, apresiasi sastra, keteladanan tokoh-tokoh sejarah dan para pemimpin bangsa.

c. pendidikan karakter berbasis lingkungan (konservasi lingkungan). 
d. pendidikan karakter berbasis potensi diri, yaitu sikap pribadi, hasil proses kesadaran pemberdayaan potensi diri yang diarahkan untuk meningkatkan kualitas pendidikan (konservasi humanis) (Yahya Khan, 2010: 2).

Setelah diberikan penjelasan tentang pendidikan karakter, tahap selanjutnya adalah mengklasifikasikan berdasarkan kriteria dan memverifikasikan kembali gagasan yang muncul. Gagasan yang diambil tentu yang berkaitan dengan pendidikan karakter. Peserta didik menyepakati bersama tentang tema yang akan diangkat dalam antologi puisi mereka. SMP Ign. Slamet Riyadi mengangkat tema tentang alam atau pendidikan karakter berbasis lingkungan, sedangkan SMP Kartika VIII - I menetapkan tema sahabat atau pendidikan karakter berbasis sikap diri pada sesamanya.

\section{Pembahasan dan Hasil}

Peserta kegiatan adalah siswa kelas VII di Ign. Slamet Riyadi dan SMP Kartika VIII - I, Jakarta Timur. Penentuan peserta kegiatan ini berdasarkan hasil wawancara guru-guru MGMP Bahasa Indonesia se-kecamatan Pasar Rebo. Dari hasil wawancara diperoleh bahwa kedua SMP tersebut memerlukan sosialisasi menulis kreatif karya sastra. Hal ini disebabkan oleh kurangnya motivasi, keberanian, pengembangan ide, dan pengembangan potensi dari siswa.

Secara umum siswa kelas VII sudah pernah mendapatkan materi tentang puisi, cerpen, dan novel. Selain itu, siswa juga pernah diminta membuat puisi oleh guru. Namun, dalam hal ini penanaman keberanian dan rasa percaya diri dalam berkarya masih kurang. Siswa masih bingung dalam memulai kegiatan menulis sehingga perlu disosialisasikan tentang pencarian ide, pengembangan, dan kreativitas dari ide yang didapat.

Kegiatan menulis kreatif di kedua sekolah tersebut dilakukan secara terpisah pada hari yang berbeda dan berlangsung dari pukul 08.00 hingga pukul 15.00. Kegiatan ini terdiri dari tiga bagian. Pertama, pengenalan dan pemahaman gerakan literasi sekolah dan manfaatnya. Dengan menggunakan metode ceramah berdiskusi, materi ini dapat tersampaikan dengan baik dan siswa menjadi aktif. Selain siswa diberikan pengertian tentang literasi, siswa juga diajak menemukan bentuk-bentuk literasi di era digital sekarang ini, dan bagaimana secara cerdas menangkal berita hoax. Banyak informasi pengetahuan yang tidak berdasarkan data. Kedua, siswa diajak menemukan dan menggali ide dengan menggunakan brainstorming. Hal ini 
berkaitan dengan tanggung jawab dalam pembinaan menulis karya sastra yaitu memunculkan potensi kreatif dalam bidang kesastraan, seperti mengembangkan ide. Contohnya, tim abdimas menayangkan sebuah gambar dan siswa diminta menyebut satu kata yang dapat mewakili gambar tersebut seperti kesedihan, bencana, kematian, duka, menangis, dan sebagainya. Setelah itu siswa dipancing dengan satu kata yang menunjukkan tempat kejadian dan harus dilengkapi oleh satu kata lagi. Misalnya:

Indonesia..... (berduka)

Yogyakarta ..... (menangis)

Kampungku ..... (luluh)

Ketiga, dengan menggunakan metode demonstrasi, siswa diajak bersama-sama membuat satu karya puisi dengan tim abdimas serta mahasiswa dan alumni yang merupakan seorang penulis terkenal dan sudah banyak menghasilkan karya. Hal ini melatih mengembangkan kemampuan dalam menuangkan potensi kreatif tersebut ke dalam bentuk tulis. Metode demonstrasi ini misalnya dengan menggunakan teknik pemasangan kata. Teknik pemasangan kata ini berpusat pada keberanian memasang-masangkan kata secara bebas tetapi imajinatif. Dengan ini akan dimungkinkan munculnya kata-kata baru yang imajinatif pula. Kemudian, dari pemunculan kata-kata baru yang imajinatif tersebut secara potensial dapat dikembangkan menjadi larik yang menarik, selanjutnya menjadi bait dan disempurnakan menjadi puisi yang utuh.

Dalam pemasangan atau perangkaian kata ini dibutuhkan keberanian untuk tidak terjebak pada ketakutan apakah kata yang dirangkai salah atau benar sesuai kaidah bahasa Indonesia. Dalam menulis puisi tidak mengenal kaidah penulisan bahasa Indonesia yang benar tetapi yang dikenal adalah licencia poetika. Licentia poetica oleh Shaw (1972:291) dikatakan sebagai kebebasan seorang sastrawan untuk menyimpang dari kenyataan, dari bentuk atau aturan konvensional, untuk menghasilkan efek yang dikehendaki. Dengan kata lain, licentia poetica merupakan kebebasan memanipulasi kata oleh penyair demi menimbulkan efek tertentu dalam karyanya dan terkadang menabrak kaidah dasar berbahasa. Contoh:

Kata "bulan" dipasangkan dengan kata $\rightarrow$ rindu, senja, mandi di bibir pantai,

Bulan sendu, dsb.

Kata "mata" dipasangkan dengan kata $\rightarrow$ lupa, merayu, gelisah, dsb. 
Dari kegiatan menulis kreatif sastra, terutama puisi pada dua sekolah yaitu SMP Ign. Slamet Riyadi dan SMP Kartika VIII - I Jakarta Timur, diperoleh hasil sebagai berikut:

1. Siswa sangat antusias sekali dalam kegiatan ini. Hal ini terlihat dalam keaktifannya tanya jawab dan sharing atau berbagai pengalaman yang dapat dijadikan idea tau gagasan dalam menulis.

2. Siswa sudah lebih percaya diri dengan membacakan hasil tulisannya kepada teman-teman yang lain di depan kelas.

3. Siswa berani menuliskan gagasannya, ungkapan isi hatinya dalam puisi yang akan diterbitkan dalam sebuah antologi puisi bersama.

4. Siswa semakin aktif mengisi tulisan pada PUDING (Puisi Dinding) di sekolah.

5. Siswa menjadi semakin berani tampil menghasilkan karya.

Berikut ini dua contoh puisi dari siswa SMP Ign. Slamet Riyadi dan SMP

Kartika VIII - I Jakarta Timur:

\author{
Pantai Losari \\ (Amara Caroline) \\ Keindahanmu membuat semua orang terpesona \\ Pasirmu bagaikan permata \\ Menyambut ombak dari jauh menepi \\ Senang bermain pasir dan dikejar ombak \\ Senang mencari keong di sana \\ Semoga aku bisa ke sana lagi \\ memeluk angin pantai \\ membuat hatiku damai
}

Jakarta, 2 Mei 2018 
AN'ZILA CAHYA KAMILA

\title{
SAHABAT TERBAIKKU
}

\author{
Wajahmu selalu terbayang di mataku \\ Tawa candamu menyenangkan hatiku \\ Di saat diriku bersedih kau selalu setia menemaniku \\ Susah senang kita lewati bersama \\ Aku ingin selalu bersamamu sahabat \\ Melewati hari-hariku bersamamu \\ Kau bintang di hatiku \\ Tiada yang bisa menggantikanmu di hatiku \\ Semoga persahabatan kita selamanya terjalin \\ Sampai maut memisahkan
}

Jakarta, 8 Mei 2018

\section{Penutup}

Kegiatan menulis kreatif sastra yang dilakukan pada hari pengembangan diri sekolah dapat membuahkan hasil yang baik dan bermanfaat bagi siswa terutama yang menyukai cipta sastra. Meskipun kegitan ini dilakukan satu hari penuh, siswa tidak merasa jenuh. Hal ini dilakukan dengan tiga metode yaitu ceramah berdiskusi yang menyenangkan, brainstorming penuh permainan, dan metode demonstrasi yang menarik dengan melibatkan tim abdimas baik dosen, mahasiswa maupun alumni yang sudah banyak menuliskan karya sastra. Karya seseorang merupakan gagasan dan ungkapan murni dirinya yang patut dihargai. Oleh karena itu, hasil luaran kegiatan ini adalah antologi puisi karya siswa-siswa peserta sosialisasi ini. Diharapkan kegiatan ini dalam berlangsung secara rutin di setiap sekolah sehingga di masa muda para siswa sudah terbiasa berkarya dan gerakan literasi sekolah menjadi gerakan yang terwujud secara nyata dan manfaatnya dapat dirasakan oleh generasi penerus bangsa, 


\section{Daftar Pustaka}

Huda, Miftahul. (2014). Model-model Pengajaran dan Pembelajaran. Yogyakarta: Pustaka Pelajar.

Khan, Yahya. (2010). Pendidikan Karakter Berbasis Potensi Diri, Mendongkrak Kualitas

Pendidikan. Jakarta: Pelangi Publishing.

Retnaningsih, Pratiwi, dkk. (2016). Panduan Gerakan Literasi Sekolah di Sekolah Menengah Pertama. Jakarta: Direktorat Jenderal Pendidikan Dasar dan Menengah Kementrian Pendidikan dan Kebudayaan.

Riris K, Toha-Sarumpaet. (2002). Sastra Masuk Sekolah. Bandung: Anggota IKAPI.

Roestiyah N.K. (2001). Strategi Belajar Mengajar. Jakarta. Rineka Cipta.

White, Ron and Valerie Arndt. (2000). Process Writing. London and New York: Longman Handbooks for Language Teacher.

\section{LAMPIRAN}

\section{Hasil Luaran Abdimas}
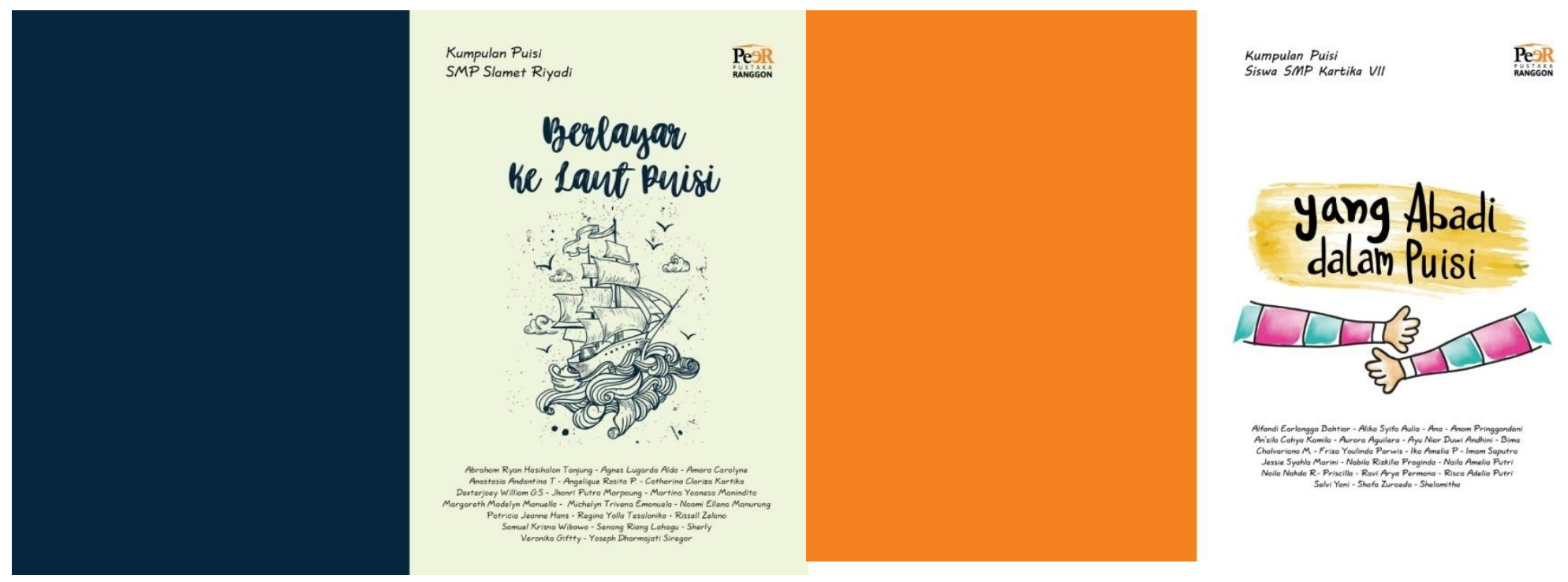